Available online on 15.01.2021 at http://jddtonline.info
O 2011-21, publisher and licensee JDDT, This is an Open Access article which permits
unrestricted non-commercial use(CC By-NC), provided the original work is properly cited
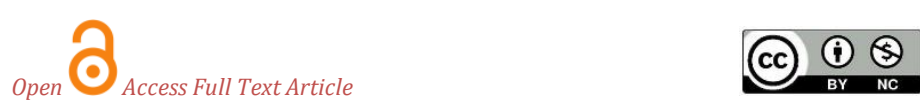

Review Article

\title{
Methylcobalamine (Vitamin B12): Water Soluble Vitamin with Various Pharmacological Aspect
}

\author{
Roopesh Kumar Yadav, Sudhanshu Mishra*, Deepti Jain \\ School of Pharmaceutical Science, Rajiv Gandhi Prodyogiki Viswavidyalaya, Bhopal, India
}

\begin{tabular}{l} 
Article Info: \\
\hline Article History: \\
Received 06 Oct 2020; \\
Review Completed 19 Dec 2020 \\
Accepted 27 Dec 2020; \\
Available online 15 Jan 2021
\end{tabular}

Cite this article as:

Yadav RK, Mishra S, Jain D, Methylcobalamine (Vitamin B12): Water Soluble Vitamin with Various

Pharmacological Aspect, Journal of Drug Delivery and Therapeutics. 2021; 11(1):130-137

DOI: http://dx.doi.org/10.22270/jddt.v11i1.4488

*Address for Correspondence:

Sudhanshu Mishra, Assistant Professor, Dr M C Saxena

College of Pharmacy, IIM Road Lucknow, India

\begin{abstract}
Vitamin B12 is a water-soluble vitamin that plays a key role in the brain's proper functioning and nervous system, in blood flow, and in reducing weakness and tiredness. In their food, most people get adequate vitamin B12, but in some health conditions (e.g. inadequate sleep, stomach/intestinal disorders, inflammation, cancer), there could be a shortage. If left unchecked, severe Vitamin B12 deficiency results in anemia and nerve damage. Vitamin B12 deficiency is typically treated using parenteral and oral dosage formulations, but absorption and compliance problems are involved with these routes of administration. Most significantly, the function of this missing intrinsic factor has been shown to assist in vitamin B12 absorption and a deficiency known as pernicious anaemia. Vitamin B12 is only partially absorbed when delivered by mouth to patients with pernicious anemia, but hematologically re-absorbed in patients with pernicious anemia. Parenteral administration of the extrinsic element will treat pernicious anaemia satisfactorily. There are several roles and advantages of vitamin B 12 in the human body with therapeutic effects also.
\end{abstract}

Keywords: Water Soluble Vitamins, Methylcobalamine, Vitamin B12, Pernicious Anaemia.

\section{INTRODUCTION-}

Although they serve many roles in the body, vitamins and minerals are fundamental supplements. There is a barely recognizable distinction between getting enough (which is solid) of these supplements and getting too much (which create overdose). The only way to get sufficient proportions of the vitamins and minerals required by our body remains to eat a solid regimen. ${ }^{1}$ Vitamins and minerals are seen as important nutrients because they have diverse functions in many ways, such as assisting in bone metabolism, wound healing, and building up our body structure, and even converting nourishment into vitality and restoring cell damage. ${ }^{2}$

\section{Types of Vitamins}

Fat-soluble vitamin- The adipose tissues of the body and the liver store fat-soluble vitamins. The A, D, E, and K vitamins are fat-soluble. ${ }^{3}$ These are less demanding to store than water-soluble vitamins, and they will remain in storage form in the body for a long amount of time, and a few months in some cases. In the digestive tract, fat-soluble vitamins are absorbed with the aid of fats or lipids.

Water-soluble vitamin-Vitamins that are water-soluble do not survive in the body for a long time. They can't be processed by the body and they get released from urination. Water-dissolvable vitamins are expelled more often along these lines than fat-solvent ones. Water solvents are vitamin $\mathrm{C}$ and $\mathrm{B}$ vitamins. ${ }^{4}$

Vitamin B12 is a water-soluble vitamin that plays a crucial role in the proper functioning of the brain and nervous system, blood production, and stress and fatigue control. 5,6

- $\quad$ Types of vitamin B12

$>$ Methylcobalamin (A most active form of vitamin B12)

$>$ Hydroxycobalamin

$>$ Adenosylcobalamin

$>$ Cyanocobalamin

Healthy diet sources of vitamin B-12 include: milk products such as milk, cheese and yogurt, beef, fish, chicken, eggs, certain nutritional yeast products and mushrooms, certain kinds of soy milk, and breakfast cereals are enriched with vitamin B-12. Before active therapy is needed, it is often best to sustain a balanced diet and consume healthy quantities of nutrients. For a balanced diet, the signs of malnutrition are easily eroded.7,8

\section{Benefits of Vitamin-B12}

- For the proper function of the brain and the nervous system, vitamin B-12 is essential. It is also active in red blood cell development and helps to produce and control DNA. 
- $\quad$ Each cell in the body's metabolism relies on vitamin B12 since it plays a role in the fatty acid synthesis and the production of energy. By helping the human body digest folic acid, vitamin B-12 helps the release of energy. ${ }^{9}$

- Millions of red blood cells are generated by the human body every minute. Without vitamin B-12, these cells do not replicate properly. Red blood cell production is decreased if the levels of vitamin B-12 are too low. Anemia may occur if the count of red blood cells decreases. ${ }^{10}$

Absorption of Vitamin B12- It is protein-bound as humans take vitamin B12 orally. There is also some preliminary evidence that unbound B12 can be actively absorbed in higher rates through the membranes under the tongue than through passive diffusion in the digestive tract, especially when combined with an absorption enhancer. ${ }^{11}$ When the protein-B12 complex reaches the intestine, the stomach secretes acids and enzymes that separate B12 from the protein. Another protein that takes up and brings B12 through the small intestine and the stomach is R-protein (aka cobalophilin, haptocorrin, and transcobalamin I). The stomach cells also produce a protein called intrinsic factor (IF) that passes to the small intestine (R-protein is found in saliva and stomach). The cobalamins then take the final part of the small intestine, the ileum, to the intrinsic portion. 12 Through passive diffusion, certain inactive B12 analogs are most likely absorbed. About 60 percent of the overall volume of B12 in the body is contained in the liver and 30 percent is stored in the muscles. People typically secrete $1.4 \mu \mathrm{g} /$ day of B12 through their bile through their small intestines. It binds to transcobalamin II-II after B12 is absorbed into the intestinal cells (TC2). Transcobalamin II captures B12 and passes it to other body tissues via the blood and cerebrospinal fluid. While B12 is transferred to cells by transcobalamin II, haptocorrin is present in around 3/4 of B12 in the blood (aka transcobalamin I and cobalophilin). B12 is released from TC2 in the form of hydroxocobalamin until the B12-TC2 complex enters the cell where it is required. ${ }^{13}$ It is then converted into methylcobalamin or adenosylcobalamin and used by its respective enzymes. Transcobalamin II also transports B12 to the liver for transcobalamin III storage. Excess B12 is excreted in the urine. This usually occurs only after injection of B12.14

\section{STRUCTURAL CHARACTERISTICS AND CHEMISTRY OF VITAMIN B12-}

Vitamin B12 is a class of cobalt and corrin ring molecules that possess vitamin activity. The sixth coordination site of the corrin ring is either a cyano group (-CN), a hydroxyl group $(-\mathrm{OH})$, a methyl group (-CH-) or a 5 '-deoxyadenosine group, creating four forms of vitamin B, including, cyanocobalamin, hydroxocobalamin, methylcobalamin, and adenosylcobalamin. ${ }^{15,16}$

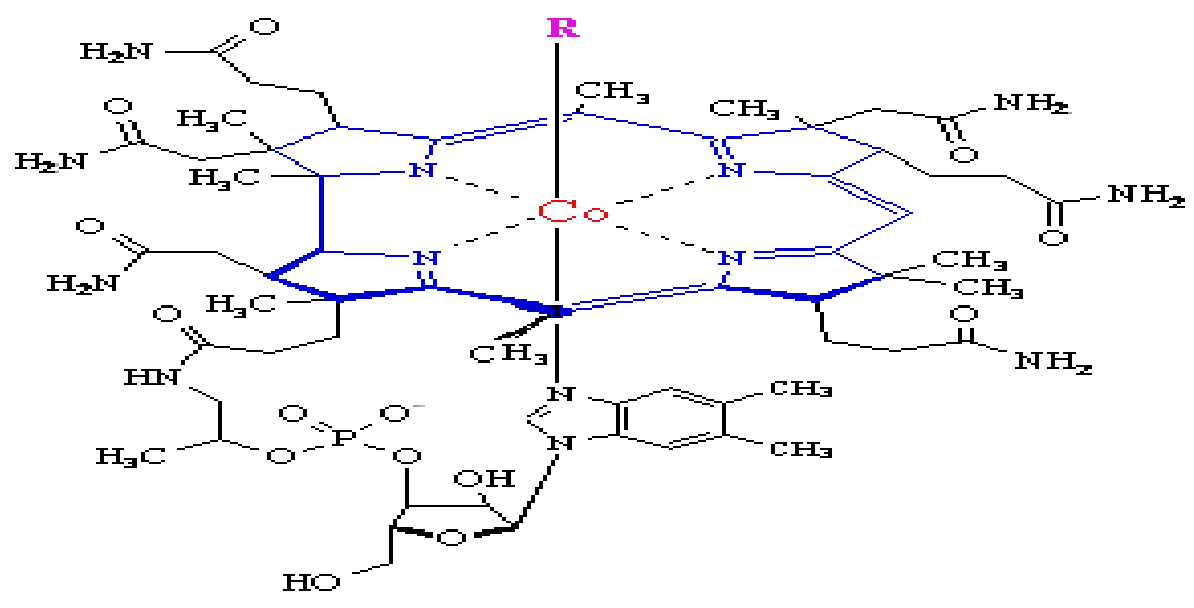

Figure 1: Structure of Vitamin B12

Solubility: Solubilized in organic solvents that are expelled with inert gas, such as ethanol and DMSO.17 The solubility of vitamin B12 is approximately 10 and $75 \mathrm{mg} / \mathrm{ml}$, respectively, in these solvents. In water, vitamin B12 is also soluble at a concentration of $50 \mathrm{mg} / \mathrm{ml} .{ }^{18}$

Stability/Shelf Life: Light-sensitive, Hygroscopic; when exposed to air, may absorb about $12 \%$ water. $^{19}$

\section{Pharmacokinetics-}

Absorption: Readily absorbed in ileum and sublingual routes by passive diffusion. Dietary vitamin B12 is present in conjunction with food proteins and must be released inside the gastric lumen at low $\mathrm{pH}$ exposure to promote absorption in the small intestine. Individuals intake roughly $2.4 \mu \mathrm{g}$ of vitamin B12 every day, of which about $50-60 \%$ is absorbed.20,21
Protein binding- Very high.

Metabolism: Occurred in the liver.

Biological half-life: 6 days.

Elimination: Urine/Bile

\section{TYPES OF FORMULATIONS USED FOR VITAMIN B12 DELIVERY-}

There is a various formulation used to reduce the risk from the deficiency of vitamin B12 like Mucoadhesive buccal tablets, Microencapsules, Lozenges, Liposomes, Buccal films, Nasal Spray, Intranasal drop, Topical microemulsion, Oral Spray, gelatin compositions (for parenteral), pen (inhaler), buccal mucoadhesive hydrogel films and toothpaste, etc. The following table no 1.0 include the different approaches of vitamin B12 in detail-22-28 
Table 1: Comparative Table of Various Approaches of Vitamin B12

\begin{tabular}{|c|c|c|c|c|c|c|}
\hline Formulations & $\begin{array}{l}\text { Method of } \\
\text { preparation }\end{array}$ & $\begin{array}{l}\text { Formulation } \\
\text { Ingredients }\end{array}$ & $\begin{array}{l}\text { Characterization } \\
\text { method }\end{array}$ & Advantages & Disadvantages & Bioavailability \\
\hline $\begin{array}{l}\text { Mucoadhesive } \\
\text { buccal tablets }\end{array}$ & $\begin{array}{l}\text { Direct } \\
\text { compression }\end{array}$ & $\begin{array}{l}\text { hydroxypropyl } \\
\text { methyl cellulose } \\
\text { (HPMC), } \\
\text { carbopol 971p } \\
\text { (CP971p), and } \\
\text { chitosan (Cs) }\end{array}$ & $\begin{array}{l}\text { Thickness, weight, } \\
\text { drug content, } \\
\text { hardness, friability, } \\
\text { surface } \mathrm{pH} \text {, In } \\
\text { vitro drug release, } \\
\text { and mucoadhesion }\end{array}$ & $\begin{array}{l}\text { Rapid onset of } \\
\text { action, elevated } \\
\text { patient } \\
\text { acceptability, } \\
\text { administration, } \\
\text { and dose } \\
\text { removal is easy. }\end{array}$ & $\begin{array}{l}\text { Low } \\
\text { effectiveness in } \\
\text { terms of flavor, } \\
\text { irritation, low } \\
\text { permeability, } \\
\text { and patient } \\
\text { acceptability. } \\
\text { Less surface } \\
\text { area also. }\end{array}$ & $\begin{array}{l}\text { up to } 2.7- \\
\text { folds that of } \\
\text { Neurotone } \\
\text { I.M.injection }\end{array}$ \\
\hline $\begin{array}{l}\text { Microencapsul } \\
\text { ation }\end{array}$ & $\begin{array}{l}\text { Spray-drying } \\
\text { technique }\end{array}$ & $\begin{array}{l}\text { Modified } \\
\text { chitosan, Vitamin } \\
\text { B-12, Deionised } \\
\text { water }\end{array}$ & $\begin{array}{l}\text { Scanning Electron } \\
\text { Microscopy, } \\
\text { particle size,UV } \\
\text { spectrophotometri } \\
\text { c method, release } \\
\text { and its stability }\end{array}$ & $\begin{array}{l}\text { Improving the } \\
\text { stability of } \\
\text { nutrition, } \\
\text { preventing } \\
\text { ingredient } \\
\text { reactions and } \\
\text { decay. The } \\
\text { coating matrix } \\
\text { essentially } \\
\text { separates } \\
\text { particles and } \\
\text { prevents them } \\
\text { from contacting } \\
\text { one another. }\end{array}$ & $\begin{array}{l}\text { High material } \\
\text { loss, Sustained- } \\
\text { release } \\
\text { preparations. } \\
\text { Time- } \\
\text { consuming. , } \\
\text { Suitable to } \\
\text { larger particles. }\end{array}$ & \\
\hline $\begin{array}{l}\text { Microencapsul } \\
\text { ation }\end{array}$ & $\begin{array}{l}\text { Emulsion } \\
\text { technique }\end{array}$ & $\begin{array}{l}\text { Vitamin B-12, } \\
\text { PEG - 6000, } \\
\text { Shellac, Liquid } \\
\text { Paraffin, } \\
\text { Acetone, } \\
\text { Cyclohexane, } \\
\text { Mannitol, Tween } \\
80\end{array}$ & $\begin{array}{l}\text { Strength, } \\
\text { Percentage Yield, } \\
\text { Dissolution Rate, } \\
\text { Accelerated } \\
\text { stability testing }\end{array}$ & $\begin{array}{l}\text { Higher stability, } \\
\text { prevent their } \\
\text { deterioration, } \\
\text { preventing } \\
\text { ingredient } \\
\text { interactions }\end{array}$ & & \\
\hline $\begin{array}{l}\text { Hard gelatin } \\
\text { capsules }\end{array}$ & & $\begin{array}{l}10 \mathrm{mg} \text { vitamin } \\
\mathrm{B} 12,10 \mathrm{~g} \text { vitamin } \\
\mathrm{B} 1,10 \mathrm{~g} \\
\text { riboflavin, } 50 \mathrm{~g} \\
\text { niacinamide,5 g } \\
\text { calcium } \\
\text { pantothenate, } 4.5 \\
\text { grains desiccated } \\
\text { whole liver, } 1980 \\
\text { g of iron }\end{array}$ & $\begin{array}{l}\text { Weight variation, } \\
\text { content Uniformity } \\
\text { Disintegration } \\
\text { time, Dissolution } \\
\text { time }\end{array}$ & $\begin{array}{l}\text { tasteless, } \\
\text { odorless, easy to } \\
\text { administrate, } \\
\text { Attractive to } \\
\text { appearance, Easy } \\
\text { to handle and } \\
\text { carry. }\end{array}$ & absorb water & \\
\hline $\begin{array}{l}\text { Lozenges } \\
1000 \mathrm{mcg}\end{array}$ & & $\begin{array}{l}\text { Folate } 42 \%, \\
\text { Vitamin B-12(as } \\
\text { Cyanocobalamin) } \\
41,667 \%, \text { Fructo } \\
\text { se, } \\
\text { Microcrystalline } \\
\text { Cellulose, } \\
\text { Sorbitol, Natural } \\
\text { Flavors, Stearic } \\
\text { Acid (vegetable } \\
\text { source), } \\
\text { Magnesium } \\
\text { Stearate } \\
\text { (vegetable } \\
\text { source) and } \\
\text { Silicon Dioxide. }\end{array}$ & $\begin{array}{l}\text { Particle size } \\
\text { distribution, } \\
\text { moisture content, } \\
\text { flow, blend } \\
\text { uniformity, } \\
\text { hardness, tablet } \\
\text { weight, thickness }\end{array}$ & $\begin{array}{l}\text { Increase the } \\
\text { retention time of } \\
\text { the dosage form, } \\
\text { increases } \\
\text { bioavailability } \\
\text { reduces gastric } \\
\text { irritation and } \\
\text { bypasses the } \\
\text { first-pass } \\
\text { metabolism. }\end{array}$ & $\begin{array}{l}\text { No drinking or } \\
\text { eating before } \\
\text { or during use. } \\
\text { Should not be } \\
\text { swallowed }\end{array}$ & \\
\hline Liposomes & & $\begin{array}{l}\text { Phosphatidylchol } \\
\text { ines, glycerin, } \\
\text { natural orange } \\
\text { flavor, stevia, } \\
\text { potassium }\end{array}$ & $\begin{array}{l}\text { Size-around } \\
\text { 450nm positive } \\
\text { surface charge, } \\
\text { loading efficiency }\end{array}$ & $\begin{array}{l}\text { Increase } \\
\text { absorption and } \\
\text { bioavailability } \\
\text { Improve their } \\
\text { transit across the }\end{array}$ & $\begin{array}{l}\text { high } \\
\text { production } \\
\text { cost., may } \\
\text { undergo } \\
\text { oxidation and }\end{array}$ & \\
\hline
\end{tabular}




\begin{tabular}{|c|c|c|c|c|c|c|}
\hline & & $\begin{array}{l}\text { sorbate, vitamin } \\
\text { B12, purified } \\
\text { water }\end{array}$ & & $\begin{array}{l}\text { barriers of the } \\
\text { gastrointestinal } \\
\text { tract. Improve } \\
\text { the therapeutic } \\
\text { efficacy of } \\
\text { dietary } \\
\text { supplements }\end{array}$ & $\begin{array}{l}\text { hydrolysis, } \\
\text { Shorter half- } \\
\text { life. Lower } \\
\text { solubility. }\end{array}$ & \\
\hline Buccal films & $\begin{array}{l}\text { By positron } \\
\text { annihilation } \\
\text { lifetime } \\
\text { spectroscopy }\end{array}$ & $\begin{array}{l}\text { vitamin B12, } \\
\text { sodium alginate, } \\
\text { and Carbopol } \\
71 \mathrm{G}\end{array}$ & $\begin{array}{l}\text { Dissolution test, } \\
\text { weight, thickness, } \\
\text { surface pH, } \\
\text { swelling index, } \\
\text { drug content } \\
\text { uniformity, in } \\
\text { vitro residence } \\
\text { time, folding } \\
\text { endurance in } \\
\text { vitro release, and } \\
\text { permeation } \\
\text { studies. }\end{array}$ & $\begin{array}{l}\text { Preferable over } \\
\text { tablets in terms } \\
\text { of flexibility and } \\
\text { thinness thus } \\
\text { being less } \\
\text { obtrusive and } \\
\text { more acceptable } \\
\text { to the patient }\end{array}$ & $\begin{array}{l}\text { Eating and } \\
\text { drinking may } \\
\text { become } \\
\text { restricted, the } \\
\text { possibility of } \\
\text { the patient } \\
\text { swallowing the } \\
\text { dosage form. }\end{array}$ & \\
\hline $\begin{array}{l}\text { Nasal Spray } \\
\text { Once weekly }\end{array}$ & & $\begin{array}{l}\text { Sodium citrate, } \\
\text { citric acid, and } \\
\text { glycerin and } \\
\text { benzalkonium } \\
\text { chloride in } \\
\text { purified water }\end{array}$ & $\begin{array}{l}\text { pH between } 4.5 \\
\text { and } 5.5 . \text { spray } \\
\text { pattern, } \\
\text { Accelerated } \\
\text { Stability at a } \\
\text { higher } \\
\text { temperature }\end{array}$ & $\begin{array}{l}\text { Flexible and } \\
\text { patient } \\
\text { compliance }\end{array}$ & $\begin{array}{l}\text { Irritation of } \\
\text { nasal mucosa } \\
\text { and can be } \\
\text { interrupted by } \\
\text { respiratory } \\
\text { disorders }\end{array}$ & $6.1 \%$ \\
\hline Intranasal & & $\begin{array}{l}\text { Cyanocobalamin } \\
0.5 \%, \\
\text { citric acid } 0.12 \% \text {, } \\
\text { sodium citrate } \\
0.32 \% \text {, glycerin } \\
2.23 \% \text {, } \\
\text { benzalkonium } \\
\text { chloride } 0.02 \% \\
\text { and } 96.79 \% \\
\text { water. }\end{array}$ & $\begin{array}{l}\text { viscosity (less than } \\
1000 \mathrm{cps} \text { ), spray } \\
\text { pattern, } \\
\text { Accelerated } \\
\text { Stability at a } \\
\text { higher } \\
\text { temperature }\end{array}$ & $\begin{array}{l}\text { Lower viscosity } \\
\text { avoids the GI } \\
\text { tract and hepatic } \\
\text { metabolism, } \\
\text { bypasses the } \\
\text { BBB enhancing } \\
\text { drug } \\
\text { bioavailability } \\
\text { and allowing a } \\
\text { lower } \\
\text { therapeutic drug } \\
\text { dose and fewer } \\
\text { systemic side } \\
\text { effects free of } \\
\text { mercury } \\
\text { compounds }\end{array}$ & $\begin{array}{l}\text { Low volume of } \\
\text { drug that can } \\
\text { be } \\
\text { administered }\end{array}$ & $7 \%$ \\
\hline Nasal Spray & $\begin{array}{l}\text { Methylcobala } \\
\text { min 500 } \\
\text { (mcg) } \\
\text { Benzalkoniu } \\
\text { m chloride } \\
0.02 \text { (mcg) } \\
\text { Glycerin } \\
\text { 223(mcg) } \\
\text { Glycofurol } \\
100 \text { (mcg) } \\
\text { Sodium } \\
\text { citrate } \\
\text { dehydrate } \\
0.38 \text { (mcg) } \\
\text { Citric acid } \\
\text { anhydrous } \\
\text { Water } 10 \text { (ml) }\end{array}$ & $\begin{array}{l}\text { pH, Osmolarity, } \\
\text { drug content, } \\
\text { appearance, a } \\
\text { transmission } \\
\text { rate }\end{array}$ & $\begin{array}{l}\text { Hepatic first-pass } \\
\text { metabolism is } \\
\text { absent, Rapid drug } \\
\text { absorption and } \\
\text { quick onset of } \\
\text { action can be } \\
\text { achieved, the } \\
\text { bioavailability of } \\
\text { larger drug } \\
\text { molecules can be } \\
\text { improved }\end{array}$ & $\begin{array}{l}\text { Suitable for } \\
\text { potent medicines } \\
\text { since it is easy to } \\
\text { spray only a } \\
\text { small amount } \\
\text { into the nasal } \\
\text { cavity. There } \\
\text { could be fewer } \\
\text { medications with } \\
\text { constant and } \\
\text { regular } \\
\text { administration. }\end{array}$ & & \\
\hline $\begin{array}{l}\text { Topical } \\
\text { micro- } \\
\text { emulsion }\end{array}$ & $\begin{array}{l}\text { Titration } \\
\text { method }\end{array}$ & $\begin{array}{l}\text { Stearylamine,twe } \\
\text { en80,span20,labr } \\
\text { afil ,propylene } \\
\text { glycol ,oleic acid }\end{array}$ & $\begin{array}{l}\text { (DSC), X-ray } \\
\text { diffraction, } \\
\text { particle size, } \\
\text { conductivity, }\end{array}$ & $\begin{array}{l}\text { Facilitate in } \\
\text { preparing, } \\
\text { perfect stability, } \\
\text { increasing speed }\end{array}$ & $\begin{array}{l}\text { A large } \\
\text { concentration } \\
\text { of surfactant } \\
\text { and co- }\end{array}$ & \\
\hline
\end{tabular}




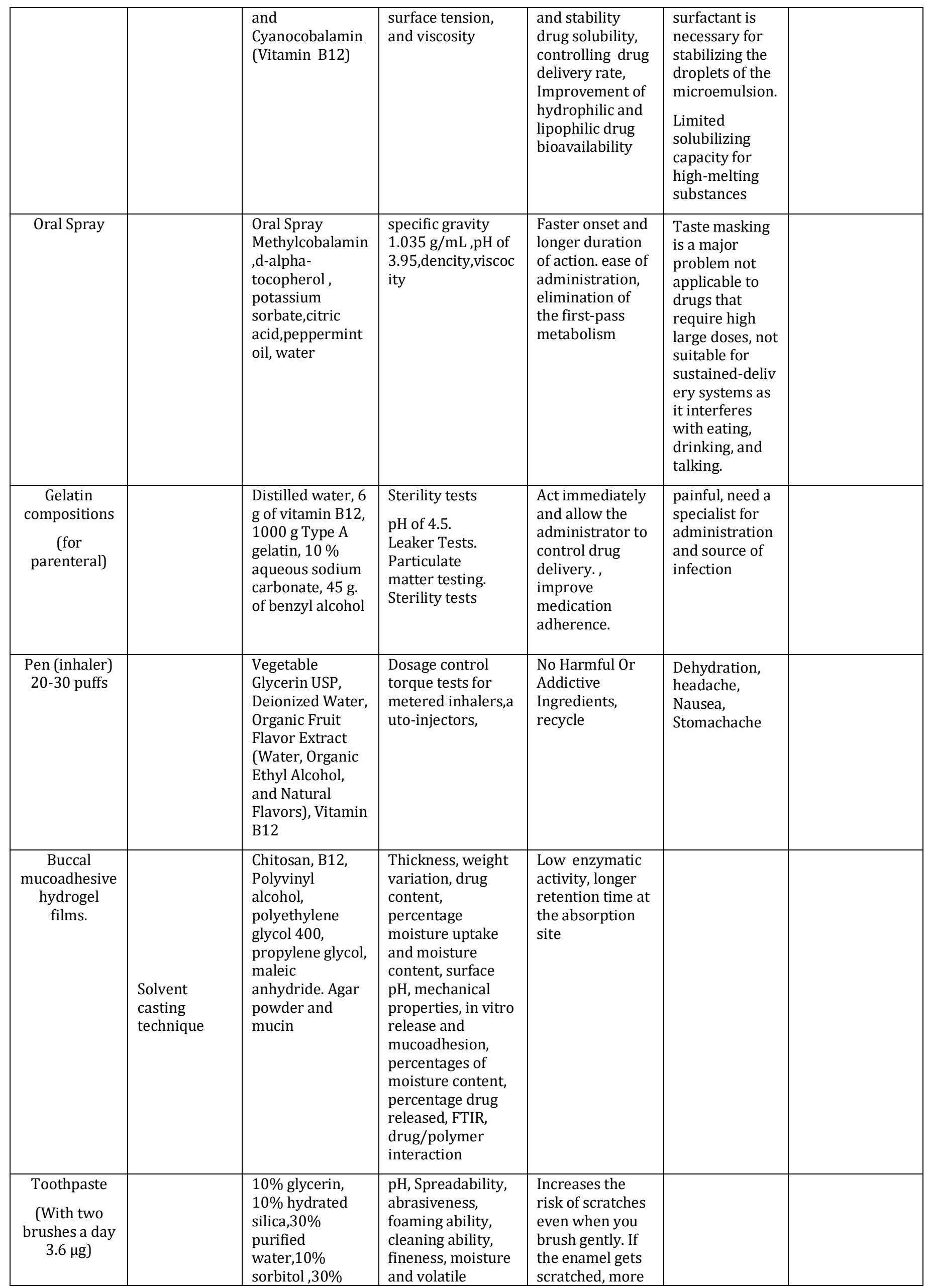




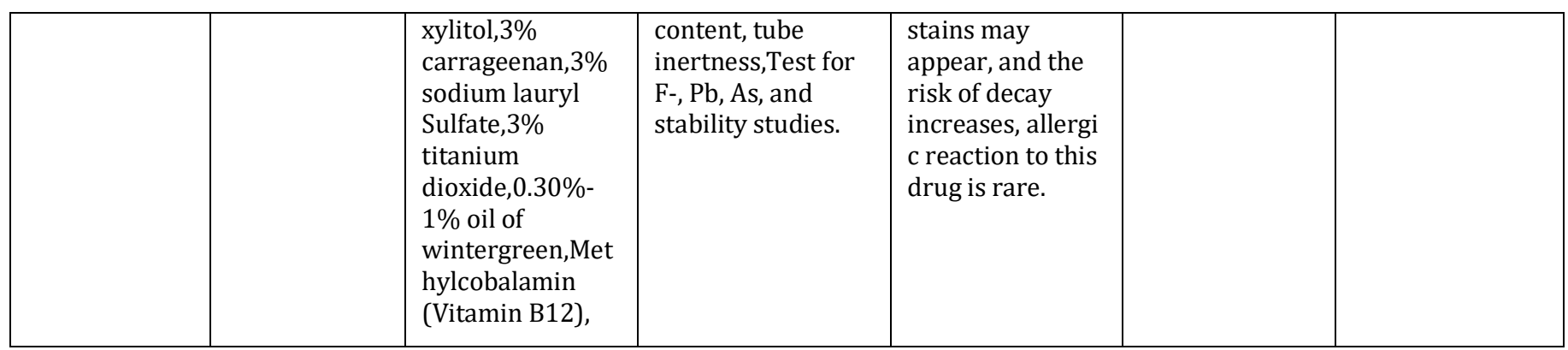

\section{COMMON POINTS}

For the treatment of pernicious anemia, we administered oral methylcobalamin 3 times per day, which provides a total of $1000 \mu \mathrm{g}$ of methylcobalamin daily, oral sprays of vitamin B12 delivers $(0.3 \mathrm{~mL})$. Common ingredients of vitamin B12 formulations are (Vitamin B12), potassium sorbate, Deionised water. The $\mathrm{pH}$ of all the formulations are found to be 4.5 to $6.5^{29}$

\section{STORAGE CONDITIONS}

Methylcobalamin is a substance that is susceptible to light and can thus be shielded from light. In cartons, keep the formulation sealed until it is fit for use. Hold upright at a controlled room temperature of $59^{\circ} \mathrm{F}$ to $86^{\circ} \mathrm{F}\left(15^{\circ} \mathrm{C}\right.$ to 30 ${ }^{\circ} \mathrm{C}$ ). Protect from the freezing of the formulation. ${ }^{30}$

\section{COMPARISON BETWEEN VARIOUS FORMULATIONS OF VITAMIN B12}

Cost: Suggested retail prices indicate that the cost of oral Vitamin B12 therapy at a dose of one Also high compared to buccal and parenteral dosage form buccal patches are cheap compared to the other two formulations. $1000 \mu \mathrm{g}$ tablet daily is approximately equivalent to the cost of taking $500 \mathrm{mg}$ of calcium and 1000 IU of Vitamin D [24]. As the dose of the drug given by oral is high, the cost is also high compared to the other two formulations. 31

Safety: Vitamin B12 injections can be dangerous in anticoagulated patients Hypo-kalmia and cardiac arrest has been reported when megaloblastic anemia is treated intensively. Pain full and require assistance. Oral administration is safe compared to intramuscular injection but requires $1000 \mu \mathrm{g}$ $2000 \mu \mathrm{g}$ per day. buccal patches are convenient, safe, and easy to insert and the low drug is required prolonged effect can be obtained. 32,33

\section{Various Functions of Vitamin B12 in Human Body-}

The significant reactions involved in vitamin B12 metabolism describe its critical role in several physiological processes. Vitamin B12's main purposes are summed up as follows: ${ }^{34}$
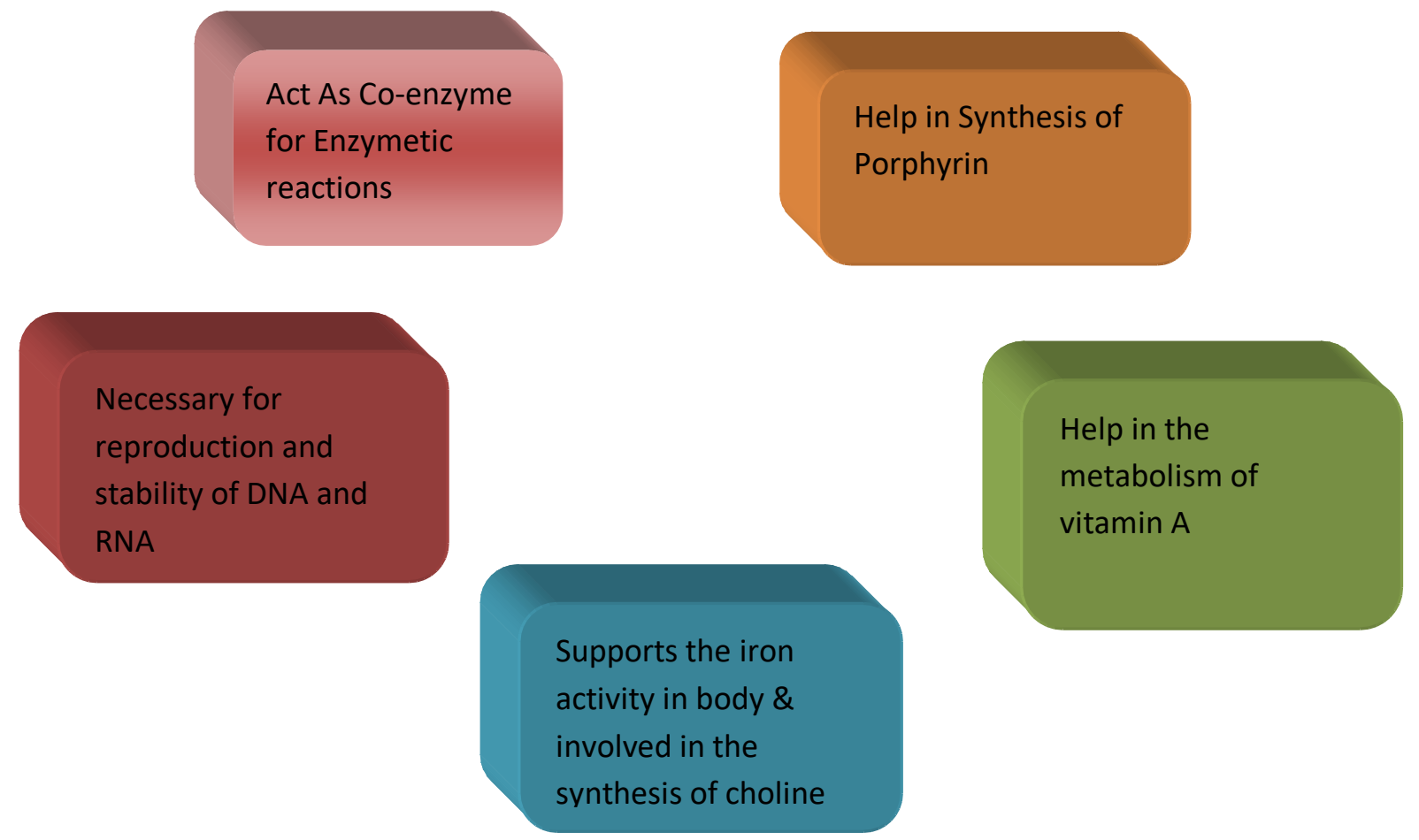

Figure 2: Functions of Vitamin B12 in Human Body 


\section{Deficiency and abundance of vitamin B12-}

A common diagnosis, especially in older adults, is vitamin B12 deficiency. The deficiency is also attributed to gene mutations that encode essential proteins in the metabolism of cobalamin, diet (vegetarian, vegan diet) and decreased production of stomach acids needed for vitamin B12 to be absorbed. Other common causes are pernicious anemia (malabsorption of vitamin B12); atrophic gastritis; gastrectomy; Zollinger-Ellison syndrome; intestinal diseases, especially of the ileum (celiac disease, Crohn's disease, ileitis); pancreatic insufficiency; parasitism; bacterial overgrowth; medicament use (antiepileptic agents, proton pump inhibitors, histamine receptor antagonists, metformin, antibiotics); diabetes mellitus; renal insufficiency; smoking; and alcohol abuse. Although vitamin B12 deficiency has been intensively studied, in the literature the reverse condition, abnormally high levels, is scarcely discussed. In both circumstances, elevated plasma levels (when not associated with external supply) lead to an improvement in vitamin B12 metabolism, either increased synthesis or reduced B12binding protein clearance. 35

\section{Safety and Precautions-}

$>$ For pregnant or breast-feeding mothers, vitamin B12 is Possibly Healthy when taken by mouth in the quantities prescribed. $2.6 \mathrm{mcg}$ a day is the optimal level for pregnant women. No more than $2.8 \mathrm{mcg}$ a day can be taken by breastfeeding females

$>$ Post-operative stent placement: Avoid using a vitamin B12, folate, and vitamin B6 mixture when having a coronary stent. This combination can increase the risk of narrowing of the blood vessels.

$>$ Should not use vitamin B12cIn Allergy or sensitivity to cobalt or cobalamine conditions.

$>$ Do not take Vit B12 Inherited eye disease, Leber's disease It will severely affect the optic nerve, which may lead to blindness. ${ }^{36}$

\section{CONCLUSION}

The intramuscular approach is uncomfortable and requires medical dosing assistance and is very expensive since it absorbs faster, the retention time is short (fast reaction). Since the GI tract is a lipid-based membrane, oral ingestion of B12 requires a significant volume of drug, and being more hydrophobic in nature is less desirable for the absorption of vitamin B12 hydrophilic drug. From the above details, the oral route is more reliable in the treatment of pernicious anemia, improves the bioavailability of vitamin B12, and there are particular advantages to this route of drug delivery, including bypassing the first-pass effect and preventing presystemic removal inside the GIT.

\section{REFERENCES}

1. Sarti F, Müller C, Iqbal J, Perera G, Laffleur F, Bernkop-Schnürch A. Development and in vivo evaluation of an oral vitamin B12 delivery system. European Journal of Pharmaceutics and Biopharmaceutics. 2013 May 1; 84(1):132-7.

2. Narang N, Sharma J. Sublingual mucosa as a route for systemic drug delivery. Int J Pharm Pharm Sci. 2011; 3(Suppl 2):18-22.

3. Lucy JA, Dingle JT. Fat-soluble vitamins and biological membranes. Nature. 1964 Oct 10; 204(4954):156-60

4. Arnstein HR, Simkin JL. Vitamin B12 and Protein Biosynthesis: Vitamin B12 and Biosynthesis in Rat Liver. Nature. 1959 Feb 21;183(4660):523-5.

5. Stabler SP. Vitamin B12 deficiency. New England Journal of Medicine. 2013 Jan 10; 368(2):149-60.

6. Vitetta L, Zhou J, Manuel R, Dal Forno S, Hall S, Rutolo D. Route and type of formulation administered influences the absorption and disposition of vitamin B12 levels in serum. Journal of functional biomaterials. 2018 Mar; 9(1):12.

7. Stabler SP, Allen RH. Vitamin B12 deficiency as a worldwide problem. Annu. Rev. Nutr.. 2004 Jul 14; 24:299-326.

8. Heilmann S, Just T, Göktas O, Hauswald B, Hüttenbrink KB, Hummel T. Effects of systemic or topical administration of corticosteroids and vitamin B in patients with olfactory loss. Laryngo-rhino-otologie. 2004 Nov 1; 83(11):729-34.

9. Rutolo Jr DA, Hall SM, Vitetta L, Zhou Y, Coulson SM, inventors; Medlab Clinical US Inc, assignee. Transmucosal and transdermal delivery systems. United States patent application US 15/555,038. 2018 Feb 8.

10. Smith FJ, Monto RW, Rebuck JW. B-12 Inhalation Therapy in Pernicious Anemia. Transactions of the American Clinical and Climatological Association. 1953; 64:27.

11. Hua S. Advances in nanoparticulate drug delivery approaches for sublingual and buccal administration. Frontiers in Pharmacology. 2019;10.

12. Lee ES, Yum SI, inventors; Alza Corp, assignee. Permeation enhances for transdermal drug delivery compositions, devices and methods. United States patent US 6,004,578. 1999 Dec 21.

13. Gimsing P, Hippe E, Helleberg-Rasmussen I, Moesgaard M, Nielsen JL, Bastrup-Madsen P, Berlin R, Hansen T. Cobalamin forms in plasma and tissue during treatment of vitamin B12 deficiency. Scandinavian Journal of Haematology. 1982 Oct; 29(4):311-8.

14. Motwani JG, Lipworth BJ. Clinical pharmacokinetics of drugs administered buccally and sublingually. Clinical pharmacokinetics. 1991 Aug 1; 21(2):83-94.

15. Rozgony NR, Fang C, Kuczmarski MF, Bob H. Vitamin B12 deficiency is linked with long-term use of proton pump inhibitors in institutionalized older adults: could a cyanocobalamin nasal spray be beneficial?. Journal of Nutrition for the Elderly. 2010 Feb 24; 29(1):87-99.

16. Riepma KA, inventor. Sublingual administration of vitamin b12 dispersed in a hydrophobic continuous phase. United States patent application US 15/761,146.2018 Sep 20.

17. Boulos A, Desai J, Martin N, Stillman R, Udwin M, inventors; Bristol Myers Squibb Co, assignee. Vitamin formulation for cardiovascular health. United States patent US 6,914,073. 2005 Jul 5.

18. Castelli MC, Friedman K, Sherry J, Brazzillo K, Genoble L, Bhargava P, Riley MG. Comparing the efficacy and tolerability of a new daily oral vitamin B12 formulation and intermittent intramuscular vitamin B12 in normalizing low cobalamin levels: a randomized, open-label, parallel-group study. Clinical therapeutics. 2011 Mar 1; 33(3):358-71.

19. Jain K, Jayanthi C, Singh M, Roopa G, Joshi H. Comparison study of vitamin-B12 for its efficacy and bioavailability of various formulations in the treatment of pernicious anemia. International Journal of Pharmacy and Pharmaceutical Sciences. 2015; 7:13.

20. Quay SC, Aprile PC, Go ZO, Sileno AP, inventors; QOL Medical LLC, assignee. Cyanocobalamin low viscosity aqueous formulations for intranasal delivery. United States patent US 7,404,489. 2008 Jul 29.

21. Katsogiannis I, Fikioris N, Kontogiorgis C, Constantinides T. Evaluation of liposomal B12 supplementation in a case series study.

22. Monto RW, Rebuck JW, Brennan MJ. Inhalation And Nasal Instillation Of Crystalline B12 Therapy In Pernicious Anemia. Henry Ford Hospital Medical Journal. 1953; 1(1):15-20.

23. Mohamad SA, Abdelkader H, Elrehany M, Mansour HF. Vitamin B12 buccoadhesive tablets: auspicious non-invasive substitute for intra muscular injection: formulation, in vitro and in vivo appraisal. Drug development and industrial pharmacy. $2019 \mathrm{Feb}$ 1; 45(2):244-51.

24. MONTO RW, REBUCK JW. Nasal instillation and inhalation of crystalline vitamin B12 in pernicious anemia. AMA Archives of Internal Medicine. 1954 Feb 1; 93(2):219-30.

25. Rozgony NR, Fang C, Kuczmarski MF, Bob H. Vitamin B12 deficiency is linked with long-term use of proton pump inhibitors in institutionalized older adults: could a cyanocobalamin nasal spray be beneficial?. Journal of Nutrition for the Elderly. 2010 Feb 24; 29(1):87-99.

26. Chan CQ, Low LL, Lee KH. Oral vitamin B12 replacement for the treatment of pernicious anemia. Frontiers in medicine. $2016 \mathrm{Aug}$ $23 ; 3: 38$. 
27. Vidal-Alaball J, Butler C, Cannings-John R, Goringe A, Hood K, McCaddon A, McDowell I, Papaioannou A. Oral vitamin B12 versus intramuscular vitamin B12 for vitamin B12 deficiency. Cochrane Database of Systematic Reviews. 2005.

28. Sanz-Cuesta T, González-Escobar P, Riesgo-Fuertes R, GarridoElustondo S, del Cura-González I, Martín-Fernández J, EscortellMayor E, Rodríguez-Salvanés F, García-Solano M, GonzálezGonzález R, Martín-de la Sierra MÁ. Oral versus intramuscular administration of vitamin B12 for the treatment of patients with vitamin B12 deficiency: a pragmatic, randomised, multicentre, non-inferiority clinical trial undertaken in the primary healthcare setting (Project OB12). BMC Public Health. 2012 Dec; 12(1):1-1..

29. Mohamad SA, Abdelkader H, Elrehany M, Mansour HF. Vitamin B12 buccoadhesive tablets: auspicious non-invasive substitute for intra muscular injection: formulation, in vitro and in vivo appraisal. Drug development and industrial pharmacy. 2019 Feb 1; 45(2):244-51..

30. Riepma KA, inventor. Sublingual administration of vitamin b12 dispersed in a hydrophobic continuous phase. United States patent application US 15/761,146. 2018 Sep 20.

31. Donangelo CM, Trugo NM, Koury JC, Barreto SM, Freitas LA, Feldheim W, Barth C. Iron, zinc, folate and vitamin B12 nutritional status and milk composition of low-income Brazilian mothers. European journal of clinical nutrition. 1989 Apr; 43(4):253

32. Sivakumar T. A Nerve Conduction study in Hypothyroid Patients with Symptomatic Vs Asymptomatic Peripheral Neuropathy in Correlation with Serum VIT B12 Level (Doctoral dissertation, KAP Viswanatham Government Medical College, Tiruchirappalli).

33. Akhtar MA. VITAMINS: USES AND MISUSES. Pakistan Armed Forces Medical Journal. 2007 Jun 30; 57(1):2-4.

34. Blakeley M, Sobczyńska-Malefora A, Carpenter G. The Origins of Salivary Vitamin A, Vitamin B12 and Vitamin D-Binding Proteins. Nutrients. 2020 Dec; 12(12):3838.

35. Kalimeri M, Leek F, Wang NX, Koh HR, Roy NC, Cameron-Smith D, Kruger MC, Henry CJ, Totman JJ. Folate and Vitamin B-12 Status Is Associated With Bone Mineral Density and Hip Strength of Postmenopausal Chinese-Singaporean Women. JBMR plus. 2020 Oct; 4(10):e10399.

36. Ao M, Inuiya N, Ohta J, Kurose $S$, Takaoka H, Abe Y, Niki N, Inoue S, Tanaka S, Miyawaki T, Tanaka K. Relationship between homocysteine, folate, vitamin B12 and physical performance in the institutionalized elderly. Journal of nutritional science and vitaminology. 2019 Feb 28; 65(1):1-7. 